\title{
RADON ACTIVITY CONCENTRATION IN DRINKING WATER IN TUZLA CITY, BOSNIA AND HERZEGOVINA*
}

\author{
Amela Kasić**, Amira Kasumović, Feriz Adrović, Muhamed Hodžić \\ Department of Physics, Faculty of Science, University of Tuzla, Tuzla, Bosnia and Herzegovina
}

\begin{abstract}
Radon is a colorless, odorless, radioactive gas. It is formed naturally from the decay of radioactive elements, such as uranium, which are found in different amounts in soil and rock throughout the world. Radon gas in the soil and rock can move into the air and into underground water and surface water. In this paper the results of measurements of radon activity concentration in drinking water from drilled wells in Tuzla City, Bosnia and Herzegovina are presented. The obtained results of radon activity concentration in drinking water samples ranged from $182 \mathrm{mBqL}^{-1}$ to $2368 \mathrm{mBqL} \mathrm{L}^{-1}$ which does not exceed the value of $11.1 \mathrm{BqL^{-1 }}$ recommended by the Environmental Protection Agency for drinking water. The measurements of radon activity concentration were conducted with AlphaGUARD and AquaKIT equipment (Genitron Instruments).
\end{abstract}

Key words: Radon activity concentration, $p H$ value, temperature, annual effective dose

\section{INTRODUCTION}

Natural radioactivity is exhibited by several elements, including uranium, radium, radon gas, and radon's daughters [1]. Natural radioactive isotopes exist in water since its formation [2]. The noble gas isotope ${ }^{222} \mathrm{Rn}$ is formed from a decay of ${ }^{226} \mathrm{Ra}$. Radon $\left({ }^{222} \mathrm{Rn}\right)$, a radioactive gas with a half-life of 3.82 days, part of the ${ }^{238} \mathrm{U}$ decay chain, is continuously produced in soil, rocks and water by natural radioactive decay of ${ }^{226} \mathrm{Ra}[1] .{ }^{222} \mathrm{Rn}$ is chemically inert and the heaviest noble gas [3]. ${ }^{222} \mathrm{Rn}$ has a high solubility in water and solubility decreases when the temperature increases. Radon is considerably more soluble in water than the lighter noble gases, about 15 times as soluble as helium and neon [4]. In various concentrations, radon is present in natural varieties, such as rocks, soil, surface water and groundwater, natural gas, but also in the air, especially in indoor environments [5].

Radon comes from the natural decay of uranium, which is present in granite rocks and soil. It may dissolve into groundwater, which can be extracted from bedrock (drilled well) or from a soil aquifer (dug well). Groundwater is favoured as a source of drinking water [6].

Ingested radon is removed from the body through exhalation while the longer-lived decay products are eliminated by urinary and fecal excretion [4]. Ingested water eventually passes through the stomach into the small intestine, where the remaining radon and decay products are released from the water and transferred to blood. They then circulate within the body; most are released from the blood into the lung and exhaled, but some remain in the blood and accumulate in organs and tissues, which receive an absorbed dose from alpha, beta, and gamma radiation [7].

Radon gas can dissolve in groundwater and can later be released into the air during such normal household activities, such as showering, dishwashing and doing laundry. Any inhaled gas, including radon, is slightly soluble in body tissues [4]. If drinking water comes from a surface water source, such as a river, lake, or reservoir, most radon that might be in the water will be released into the air before reaching the water supplier or home [7].

High radon concentrations sometimes also occur in association with pegmatites, as well as gneisses and vulcanites rich in quartz and feldspar. The concentration in ground water from bedrock is low in areas where uranium concentrations in the rocks are low (diorite, gabbro and basic vulcanites, limestone, sandstone and shale) [8]. Radon concentrations in groundwater may vary between 1 and $50 \mathrm{~Bq} / \mathrm{l}$ in sedimentary rocks, but concentrations in surface waters are low, usually below $1 \mathrm{~Bq} / \mathrm{l}$ [5].

\section{MATERIALS AND METHODS}

\subsection{Study area}

The measurement of radon activity concentration in the water samples from wells was carried out in 11 different locations in Tuzla City, Bosnia and Herzegovina. This sampled water is used only for drinking. The samples of water were collected from the wells of the Tuzla area, at the following locations: Moluhe, Solina (Solina 1, Solina 2 and Solina 3), Brđani, Obodnica (Obodnica 1 and Obodnica 2), Lipnica, Grabovica (Grabovica 1 and Grabovica 2), Sepetari.

Thy City of Tuzla is located in the Jala Basin, in the region of the northern Bosnia. The emergence of the Tuzla Basin is connected to activities that occurred in several phases after Mesozoic, causing various conditions of sedimentation. Such activities mixed with polio-climatic characteristics of that period resulted in the emergence of various and specific sediment formations.

Tertiary originated sediment formations were mainly discovered in the area of research. Limestone, followed by sand, is mostly presented comparing to 
other tertiary sediments. Besides the main formations of sediment rocks, it is important to outline the presence of lignite and coal deposits [9].

Principally, ${ }^{222} \mathrm{Rn}$ in drinking water is a problem for private well owners. At the investigated locations, private wells are often drilled or dug to supply water to individual households in Tuzla City that cannot be connected to a public water supply. Elevated radon concentrations are often encountered in water coming from wells drilled in bedrocks, containing medium to high uranium content. Radon in drinking water supplies derived from drilled wells is entirely dependent on the geochemistry of the bedrock or sands and gravels into which the well is drilled and the recharge rate of the bedrock fractures or the sand and gravel aquifer. The depth of drilled wells ranged between 6-9 meters in the investigated areas.

These measurements present the first measurements of radon activity concentrations in water from drilled wells with the AlphaGUARD method in Tuzla City, Bosnia and Herzegovina.

\subsection{Experimental set-up}

The measurements of radon activity concentration were performed by using the AlphaGUARD and AquaKIT equipment. Also, the $\mathrm{pH}$ of the water samples was measured by using the electronic $\mathrm{pH}$ meter.

The radon detector of the AlphaGUARD is based on a design-optimized pulse ionization chamber. The cylindrical ionization chamber of the AlphaGUARD has an active volume of $0.56 \mathrm{~L}$. The measuring range of this device for radon activity concentration is from $2-2 \times 10^{6} \mathrm{Bqm}^{-3}$, while the temperature range is from -10 to $50^{\circ} \mathrm{C}[10]$.

AlphaPUMP is a battery operated electronically powered handy pumping unit for gases. It can be gradually adjusted from 0.03 to $1 \mathrm{~L} /$ minute. An internal aqua-stop filter prevents any sucked liquidity from entering into the system [11].

AquaKIT is an optional accessory to the radon monitoring system AlphaGUARD PQ20ooPRO. In combination with the radon monitor and AlphaPUMP electronic pumping unit, AquaKIT allows to determine the radon concentration in water samples directly and precisely. The main condition for the correctness and exactness of the measurement of radon activity concentration in water is the appropriate sampling. The AquaKit is an attachment consisting of two glass vessels, a battery-operated pump and related piping.

A $100 \mathrm{ml}$ water sample is poured into a degassing vessel and closed tightly as fast as possible by using a special degassing cap after both AlphaGUARD and AlphaPUMP are turned on. The AlphaPUMP performance level switch is set to a flow rate of 0.3 $\mathrm{L} / \mathrm{min}$. After 10 minutes, the AlphaPUMP is switched off and the AlphaGUARD still measures the radon activity concentration for another 20 minutes. The AlphaPUMP is switched off, but the system is connected without any changes.

For the determination of radon concentration in water samples, the following equation was used:

$$
C_{\text {Water }}=\frac{C_{\text {air }} \times\left(\frac{V_{\text {System }}-V_{\text {Sample }}}{V_{\text {Sample }}}+k\right)-C_{0}}{1000}
$$

$C_{\text {water }}$ is radon concentration in the water sample [Bq $\mathrm{L}^{-1}$; $C_{\text {air }}$ is radon concentration in $\mathrm{Bqm}^{-3}$ after expelling the radon, indicated by AlphaGUARD [Bqm ${ }^{-}$ 3]; $C_{0}$ is radon concentration in the measuring equipment before sampling $\left[\mathrm{Bqm}^{-3}\right] ; V_{\text {system }}$ is the interior volume of the measurement equipment, 1.122 $\mathrm{mL} ; V_{\text {sample }}$ is the volume of the water sample $[\mathrm{mL}] ; \mathrm{k}$ is the radon diffusion coefficient.

The final result is calculated by taking into consideration the value of the diffusion coefficient, which depends on the temperature:

$$
k=0.106+0.405 e^{-0.052 T}
$$

where, $k$ is the diffusion coefficient of radon; $T$ is the temperature of water $\left[{ }^{\circ} \mathrm{C}\right][12]$.

Based on the results of the measurements of the radon activity concentration in the water sample, the annual effective ingestion dose of radon was calculated using the equation (3)

$$
H_{\text {ing }}=C_{\text {water }} \cdot D \cdot G
$$

where $H_{\text {ing }}$ is the annual effective ingestion dose for radon, [Svy $\left.{ }^{-1}\right]$ Cwater is radon activity concentration in the water sample, $\left[\mathrm{mBqL}^{-1}\right] ; D$ is the ingesting dose conversion factor of radon, $3.5 \mathrm{nSvBq}^{-1}$; $G$ is the water consumption per year $\left(60 \mathrm{~L} \mathrm{y}^{-1}\right)$. [13].

\section{RESULTS AND DISCUSSION}

The values of $\mathrm{pH}$, water temperature, and diffusion coefficient of radon in investigated water samples are given in Table 1 . The $\mathrm{pH}$ value of the investigated water samples varied in the range between 6.6 and 7.6 .

Table 1. Values of $\mathrm{pH}$, water temperature and diffusion coefficient of radon in investigated water samples in Tuzla City, Bosnia and Herzegovina

\begin{tabular}{|c|c|c|c|c|c|}
\hline No. & Locality & $\begin{array}{c}\text { Type } \\
\text { of well }\end{array}$ & $\begin{array}{c}\mathrm{T} \\
\left({ }^{\circ} \mathrm{C}\right)\end{array}$ & $\mathrm{pH}$ & $\mathrm{k}$ \\
\hline 1. & Moluhe & drilled & 16 & 7.1 & 0.28 \\
\hline 2. & Solina 1 & drilled & 19 & 7.6 & 0.26 \\
\hline 3. & Solina 2 & drilled & 19 & 7.3 & 0.26 \\
\hline 4. & Solina 3 & drilled & 13 & 7.3 & 0.31 \\
\hline 5. & Brđani & drilled & 18 & 7.5 & 0.26 \\
\hline 6. & Obodnica 1 & drilled & 12 & 7.5 & 0.32 \\
\hline 7. & Obodnica 2 & drilled & 16 & 7.1 & 0.28 \\
\hline 8. & Lipnica & drilled & 16 & 6.6 & 0.28 \\
\hline 9. & Grabovica 1 & drilled & 13 & 7.1 & 0.31 \\
\hline 10 & Grabovica 2 & drilled & 17 & 7.7 & 0.27 \\
\hline 11. & Sepetari & drilled & 18 & 7.3 & 0.26 \\
\hline
\end{tabular}


Thus, the lowest value of temperature in the tested samples of water was $12^{\circ} \mathrm{C}$ at the Obodnica 1 location, its corresponding diffusion coefficient value was 0.32 , and the highest value of temperature in the tested samples was $19^{\circ} \mathrm{C}$, at the Solina 1 and Solina 2, with the corresponding diffusion coefficient of radon of 0.26 .

The results of measurements of radon activity concentration in investigated water samples in the researched areas are presented in Table 2. The radon activity concentration in the investigated water samples varied from $182 \mathrm{mBqL}^{-1}$ to $2368 \mathrm{mBqL}^{-1}$, with an average value of $887 \mathrm{mBqL}^{-1}$. The highest value in the investigated drinking waters drilled from wells was found at the location Lipnica, $2368 \mathrm{mBqL}^{-1}$ and the lowest at the location Solina 2, $182 \mathrm{mBqL}^{-1}$.

Location Lipnica, with the obtained radon concentration activity of $2368 \mathrm{mBqL}^{-1}$, is accommodated on low-hilly terrains, with prevailing yellow-brownish soil, sands and sandstones, which probably allow radon to penetrate from the ground to the local water.

Locations Solina 1 and Solina 2, with 301 and 182 $\mathrm{mBqL}^{-1}$ of radon concentration activities obtained respectively, are accommodated in areas with mountainous relief. Location Solina 3, with 1075 $\mathrm{mBqL}^{-1}$ of radon concentration activity obtained, is accommodated in the plain area of the Solina settlement, where soils with ruinous limestone prevail.

Locations Obodnica 1 and Obodnica 2, with 2356 and $557 \mathrm{mBqL}^{-1}$ of radon concentration activities obtained, are accommodated in the base of the Majevica Mountain. Locations Grabovica and Sepetari are located near the urban part of the City of Tuzla. At the locations Grabovica 1 and Grabovica 2, 438 and $468 \mathrm{mBqL}^{-1}$ of radon concentration activities are obtained respectively. On the location Sepetari, a 727 mBqL-1 of radon concentration activity is obtained. Most of the City of Tuzla is built on recent sediment rocks containing small amounts of radon concentration.

These values do not exceed the value of 11.1 $\mathrm{BqL}^{-1}$ recommended by the Environmental Protection Agency for drinking water [12].

Also, Table 2 shows the results of estimated annual effective dose in the investigated drinking water samples. The estimated annual effective dose received by the population as a result of ingestion of water is in the range from $0.04-0.50 \mu \mathrm{Sv} \mathrm{y}^{-1}$. The highest value was recorded at the Lipnica location, $0.50 \mu \mathrm{Svy}^{-1}$, whereas the minimum value of the effective dose for radon is $0.04 \mu \mathrm{Svy}^{-1}$, recorded at the Solina 2.

These values do not exceed the reference level of $0.1 \mathrm{mSvy}^{-1}$ recommended by the World Health Organization [13] for the annual effective dose received from the drinking water from these three radioisotopes: ${ }^{222} \mathrm{Rn},{ }^{3} \mathrm{H},{ }^{4} \mathrm{~K}$.
Table 2. Values of radon activity concentration in investigated water samples in Tuzla City, Bosnia and Herzegovina

\begin{tabular}{|c|c|c|c|c|}
\hline No. & Locality & $\begin{array}{c}\text { Type of } \\
\text { well }\end{array}$ & $\begin{array}{c}\mathrm{C}_{\mathrm{w}} \\
\left(\mathrm{mBqL}^{-1}\right)\end{array}$ & $\begin{array}{c}\mathrm{H}_{\text {ing }} \\
\left(\mu \mathrm{Svy}^{-1}\right)\end{array}$ \\
\hline 1. & Moluhe & drilled & 521 & 0.11 \\
\hline 2. & Solina 1 & drilled & 301 & 0.06 \\
\hline 3. & Solina 2 & drilled & 182 & 0.04 \\
\hline 4. & Solina 3 & drilled & 1075 & 0.22 \\
\hline 5. & Brđani & drilled & 766 & 0.16 \\
\hline 6. & Obodnica 1 & drilled & 2356 & 0.49 \\
\hline 7. & Obodnica 2 & drilled & 557 & 0.12 \\
\hline 8. & Lipnica & drilled & 2368 & 0.50 \\
\hline 9. & Grabovica 1 & drilled & 438 & 0.09 \\
\hline 10 & Grabovica 2 & drilled & 468 & 0.09 \\
\hline 11. & Sepetari & drilled & 727 & 0.15 \\
\hline
\end{tabular}

\section{CONCLUSION}

The results of these measurements indicate that the radon activity concentrations in the investigated water samples are well below the recommended concentration limits. These results do not exceed the value of $11.1 \mathrm{BqL}^{-1}$ recommended by the Environmental Protection Agency for drinking water [14]. Also, in this paper, we have shown a significant influence of temperature on the level of radon concentration in water. The effective dose caused by radon is less than $0.1 \mathrm{mSv}$ as recommended by the World Health Organisation [15].

\section{REFERENCES}

1. A. Podstawczyńska and K. Kozak, "Outdoor radon $\left({ }^{222} \mathrm{Rn}\right)$ concentration in urban and rural area (Central Poland) in relation to meteorological parameters," presented at The seventh International Conference on Urban Climate, Yokohama, Japan, Jun. 29 - Jul. 3, 2009.

2. A. Kasić et al, "Levels of natural radioactivity in mineral and thermal waters of Bosnia and Herzegovina," Nukleonika, vol. 6o, no. 3, pp. 503508, 2015.

3. S.A. Paschuk et al., "Current development of radon and radium monitoring at the federal university of technology (UTFPR)," presented at the International Nuclear Atlantic Conference - INAC 2013, Recife, Brazil, Nov. 24-29, 2013.

4. Risk assessment of radon in drinking water, National Academy Press, Washington D. C., USA: 1999.

5. A. Cozma et al,"Radon and radium monitoring in several groundwaters from Rosia montana area, Romania," in Proc. of Second East European Radon Symposium, University of Niš, Serbia, 2014, pp. 9-12, 2014.

6. K. Skeppstrom, B.Olofson, "Uranium and radon in groundwater," European Water, no. 17/18, pp. 51-62, 2007.

7. J. Nikolov et al, "Radon in Drinking Water in Novi Sad," International Journal of Mathematical, Computational, Physical, Electrical and Computer Engineering, 5 (4), pp.539-542, 2011. 
8. Radon Measurements by Etched Track Detectors: Application in Radiation Protection. Earth Sciences and the Environment, S. Durrani, R Ilić, Eds., Word Scientific, 1997.

9. https://hr.wikipedia.org/wiki/Tuzla

10. AlphaGUARD, Portable Radon Monitor, User manual, Genitron Instruments, Germany, 1998.

11. AlphaPUMP, Technical Description, User manual, Genitron Instruments, Germany, 2001.

12. AquaKIT, Accessory for radon in water measurement in combination with the radon monitor AlphaGUARD, User Manual, Genitron Instruments, Germany, 1997.
13. UNSCEAR. (New York, 2006). Annex E: Sources and effects of ionizing radiation, Assessment for Radon in Homes and Workplaces.

14. Environmental Protection Agency (EPA). (USA, 1991).

15. World Health Organisation. (Geneva, 2011). Guidelines for drinking-water quality, recommendation, pp. 203-217 